\title{
Direct dating of Neolithic pottery: progress and prospects
}

\author{
Clive Bonsall, Gordon Cook, Joni L. Manson, David Sanderson \\ C. Bonsall, Department of Archaeology, University of Edinburgh, UK, C.Bonsall@ed.ac.uk \\ G. Cook, Scottish Universities Environmental Research Centre, East Kilbride, UK, g.cook@surrc.gla.ac.uk \\ J. L. Manson, Ohio Historic Preservation Office, Columbus, Ohio, USA, jmanson@ohiohistory.org \\ D. Sanderson, Scottish Universities Environmental Research Centre, East Kilbride, UK \\ D.Sanderson@surrc.gla.ac.uk
}

\begin{abstract}
Pottery sherds can be dated by four methods: (i) stylistic features; (ii) luminescence analysis of minerals within the sherd; (iii) ${ }^{14} \mathrm{C}$ assay of carbon on or within the sherd; and (iv) archaeomagnetic intensity of the sherd. Each method has its own sources of uncertainty. The results obtained by the various methods are reviewed, and the conclusion reached that a combination of at least two of the methods, where possible, is recommended in order to enhance confidence in the validity of the outcome.
\end{abstract}

IZVLEČEK - Fragmente keramike lahko datiramo na štiri načine: (i) stilne lastnosti; (ii) luminiscenčna analiza mineralov v fragmentu; (iii) analiza ${ }^{14} \mathrm{C}$ na ali v fragmentu; in (iv) arheomagnetna gostota fragmenta. Vsaka metoda je do neke mere nezanesljiva. V članku preverjamo rezultate vsake metode in ugotovimo, da je za zanesljivost in verodostojnost rezultata priporočljivo uporabiti, kadar je to mogoče, vsaj dve metodi.

KEY WORDS - Neolithic; pottery; dating; stylistic features; radiocarbon; luminescence; archaeomagnetism

\section{INTRODUCTION}

A reliable method for the direct dating of pottery would be advantageous for two fundamental reasons: (1) Pottery is often the most abundant material found on archaeological sites and is the basis of many traditional chronological frameworks for the Neolithic, especially in southeast Europe. (2) With the advent of single entity dating, using AMS, the problems of dating by association using charcoal or animal bone samples have become more apparent. At Schela Cladovei in Romania, Bonsall et al. (unpublished) chose to ${ }^{14} \mathrm{C}$ date bone tools from a Starčevo pit on the assumption that the ${ }^{14} \mathrm{C}$ ages would 'date' the pit and the pottery contained in it. However, the one-sigma age ranges fell outside the 'expected' age-range of the pottery (Fig. 1). This could arise through inaccuracies of excavation (since the pit cuts earlier archaeological features) or through deliberate backfilling of the pit with soil material containing older artefacts derived from elsewhere on the site. This example highlights the potential taphonomic problems of dating by association. Equally, it focuses attention on the question of 'archaeologically expected ages'. In the above example from Schela Cladovei, the expected age is derived from stylistic analysis of the pottery (see below), which in turn relies on good stratigraphic sequencing and associated radiocarbon dating at other sites and, of course, this introduces circularity into the chain of reasoning.

There are four methods, each with its own sources of uncertainty, which have been used to date pot- 


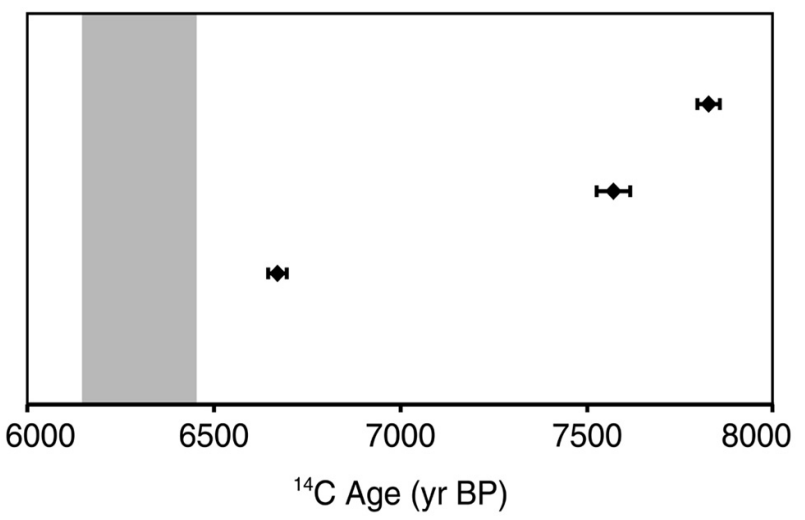

Fig. $1{ }^{14} \mathrm{C}$ dates for bone tools from a Starčevo pit at Schela Cladovei (Romania) plotted against the expected age range (stippled zone) based on stylistic dating of pottery from the pit (Bonsall et al., unpublished data).

tery. These are (i) stylistic features; (ii) ${ }^{14} \mathrm{C}$ assay of carbon on or within the sherd; (iii) luminescence analysis of minerals within the sherd; and (iv) archaeomagnetic intensity of the sherd.

\section{STYLISTIC DATING}

The oldest method of directly dating pottery involves the construction of pottery typologies and seriation techniques. The plasticity of clay allows potters to create vessels in a great variety of shapes, with a wide range of surface treatments and decorative elements, using a broad array of paste and temper combinations. For the past one hundred years, archaeologists have realized that this variability resulted in the production of ceramic styles that could be chronologically ordered (e.g. Petrie 1904; Fewkes 1935; Milojčić 1950; Aranđelović-Garašanin 1954). Ceramic styles followed a pattern of increasing popularity followed by progressively lessening popularity, which was reflected in artefact frequencies that could be graphed as the now familiar 'battleship curves'. their applications have become more widespread. Creating a pottery typology generally requires a thorough understanding of the stratigraphy of a site. The most widely used stylistic chronology for Starčevo pottery was developed by Draga AranđelovićGarašanin (1954) from an analysis of some 50000 sherds recovered during the early 1930s excavations at Starčevo-Grad, Serbia. Many of the sherds came from pit feature 5A, which Aranđelović-Garašanin considered a closed, well-stratified context. Others (Korošec 1973; Ehrich 1977) have cast doubts on the reliability of the stratigraphy of pit $5 \mathrm{~A}$ and believe any typology based on material from the pit is questionable.

Stylistic dating can also be very subjective. Both Korošec and Ehrich criticized Aranđelović-Garašanin for basing much of her typology on the painted ceramics - which accounted for less than 5\% of the total ceramic assemblage at Starčevo-Grad. Other researchers have devised slightly different pottery typologies for Starčevo ceramics (Fig. 2). Ideally, archaeologists should clearly describe the context of their artefact assemblage, the process by which they sorted the pottery into types, and their underlying assumptions. The specific goals and research questions of a project are likely to affect the variables that are chosen to construct a typology - see Whallon and Brown (1982) for a thorough discussion on this subject. Sinopoli (1991) has pointed out that only by stating explicitly the defining criteria of a typology can other researchers be expected to replicate the typology, using the same criteria at other sites, or to verify the typology, using statistical analyses.

It is not always clear what other variables may have affected the stylistic variation used to construct a pottery typology. Seriation and cross-dating between sites over a broad geographic range does not take Recognition of stylistic change through time gave archaeologists the ability to construct relative chronologies and temporal frameworks based on cross-dating (Michels 1973).

Pottery typologies are still useful chronological tools in archaeology, but their limitations have become clearer as

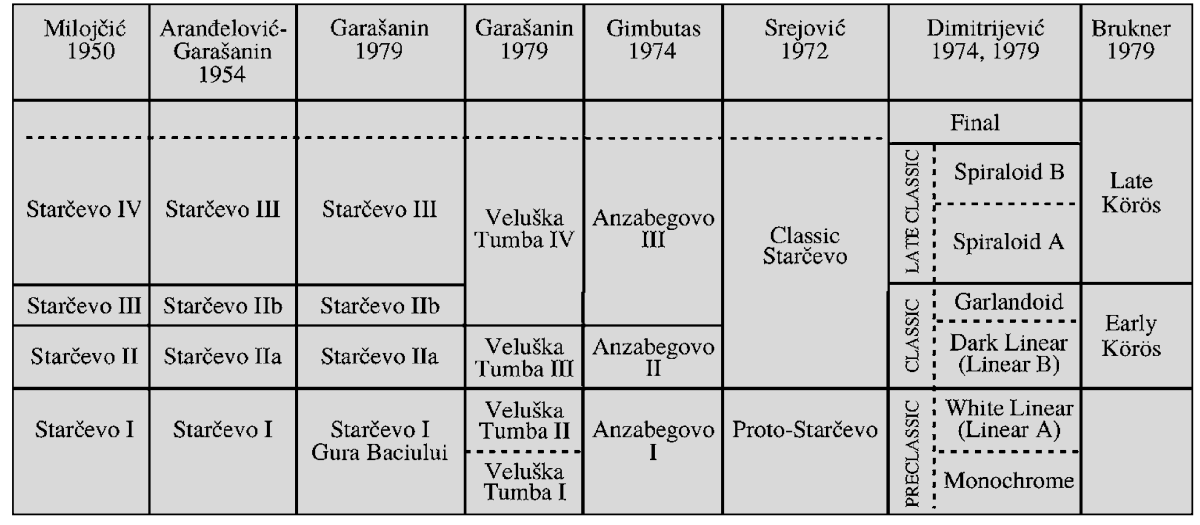

Fig. 2. Starčevo ceramic sequences (after Manson 1995). 
into account any lag time for a style to achieve peak popularity at a new location (Michels 1973; see Plog 1980 or Rice 1987 for specific examples). In the case of the typologies outlined in Figure 2, it is not clear which of the differences can be attributed to regional variation, to temporal disparity, or to cultural distinctions.

Perhaps the most important limitation on stylistic dating is that it can provide only a relative and not an absolute chronology. It must, therefore, rely on associations with other datable material in order to be assigned absolute ages. The problems of dating by association at Schela Cladovei were noted above. A thorough understanding of the site formation processes and stratigraphy are essential to identifying reliable artefact associations. Even under the best field conditions, however, verification of associations can be problematic.

In spite of the evident limitations of utilising typological approaches to chronology, which are at best indirect indicators of chronology, these methods have a central place in the history of prehistoric archaeology, and are likely to retain their place within archaeological practices. It is therefore highly desirable to obtain independent dating evidence to underpin these approaches, whenever possible. This requires both the application of absolute dating methods, and a proper understanding of the deposition processes and relationships between the time of a pot's manufacture, its use-life, and the events being dated by other means.

\section{LUMINESCENCE}

The applied timescale for luminescence dating is much wider than ${ }^{14} \mathrm{C}$, but the former usually gives poorer precision. Therefore, many laboratories have concentrated their archaeological applications on the period beyond the limit of ${ }^{14} \mathrm{C}$ dating (about 40000 yr BP), utilising burnt flints and stones, and also working on dating sediments (Prescott \& Robertson 1997; Roberts 1997). However, it is worth pointing out that luminescence dating, in the form of thermoluminescence (TL), was developed primarily for dating pottery and other forms of baked clay, such as bricks and tiles (Aitken et al. 1968; Aitken 1990), and that applications to ceramics remain the most frequently reported case studies in prehistoric and later archaeology. Moreover, there have been a number of significant technical developments in recent years with potential for improving both the range of material and events that can be dated, and also leading to improved precision. It is worth noting in this respect that the opportunities for cross-validation of such techniques against other dating evidence are far greater in Neolithic and later periods, than on applications to Lower and Middle Palaeolithic archaeology. Therefore there are good reasons for $\mathrm{da}$ ting laboratories to pursue such applications in refining the method.

Luminescence has two major advantages over radiocarbon: (1) It is an 'absolute technique', producing an age in calendar years, and (2) It directly dates the object of interest. Its limitations in respect of Neolithic pottery relate to the likely precision that can be obtained from material of this age, and the practicalities of applying the technique to a wide range of samples. Luminescence dating requires measurements of the stored radiation dose experienced by the sample since firing, and also a detailed analysis of the radiation dose-rates, or dosimetry. The stored dose is quantified using luminescence measurements of natural minerals, which are inherently variable systems, relative to calibrated laboratory radiation sources, which must be accurately and precisely calibrated. The radiation dose rates are determined by a combination of low-level radiometric methods and radiochemical techniques, which again require accurate calibration, usually based on reference materials, and also need to be able to cope with natural variations. Since part of the radiation dose rate is associated with the environment of the sample, there are significant practical advantages in making field measurements of the local gamma radiation of the burial context of the sample. The requirement for such measurements, plus the range of information needed for accurate dating, can impose significant constraints on archaeological work, as well as carrying higher costs than those associated with some other approaches.

The precision that can be achieved depends to a large extent on the sampling and sample credentials. Recent developments of newer optical readout methods have improved the precision of laboratory luminescence measurements, in some cases to better than $\pm 2 \%$. However, overall accuracy remains dependent on uncertainties in the radiation dosimetry and the influence of water content and its past variations. For these reasons the quoted uncertainties of luminescence dates are likely to remain in the 3$7 \%$ range, at least for the majority of applications. These uncertainties are proportional to the age of the sample. Thus, for a Neolithic sample of 8000 
years, $a \pm 5 \%$ uncertainty at one standard deviation corresponds to \pm 400 years, which may prove limiting for some applications. To improve on this precision, at present the only practical approach is to design projects that date groups of related objects, e.g. contemporary sherds within a well-constrained stratigraphic context. To resolve time intervals of $100-$ 150 years during the Neolithic in this manner would typically require 6-10 dating determinations per unit, which again carries cost implications. To achieve this level of precision requires (1) the availability of relatively thick sherds (minimum 7-8 mm), (2) a detailed knowledge of the position of the sherds and the "geometry" of the burial context, (3) measurements of the external dose rates (gamma ray activity of the surrounding soil, (4) retention of the original water content of the sherd and some consideration of its past variations.

According to Aitken (1990), the best conditions are when the sherd is surrounded by a homogeneous soil to a distance of $30 \mathrm{~cm}$. This is the approximate limit of penetration of gamma photons in soil. In practice, since the external components normally account for only some $30 \%$ of the total radiation dose rate, the majority of which originates from within $10 \mathrm{~cm}$ of the sample, some latitude can be allowed relative to this idealised situation. However, it is preferable that on-site measurements are taken of the gamma radiation from the surrounding soil/sediment, so that the effects of stratigraphic discontinuities can be assessed and taken into account. Otherwise laboratory measurements are made on soil and rock samples collected from the site, in addition to those from the sample.

It follows that sherds that are long removed from their original context (i.e. museum collections) present additional limitations, as the gamma background cannot normally be measured and has to be estimated. Under these circumstances, a precision of $\pm 10-20 \%$ is probably the best that can be achieved using routine approaches.

There have been several studies of European prehistoric sites that have sought to compare luminescence dates on pottery sherds with radiocarbon dates on 'associated' organic materials. Varying levels of agreement were obtained between the luminescence and ${ }^{14} \mathrm{C}$ ages.

Sherds of 'Scored Ware' from Iron Age sites in southern Britain gave luminescence dates that were in reasonable agreement with the expected age-range

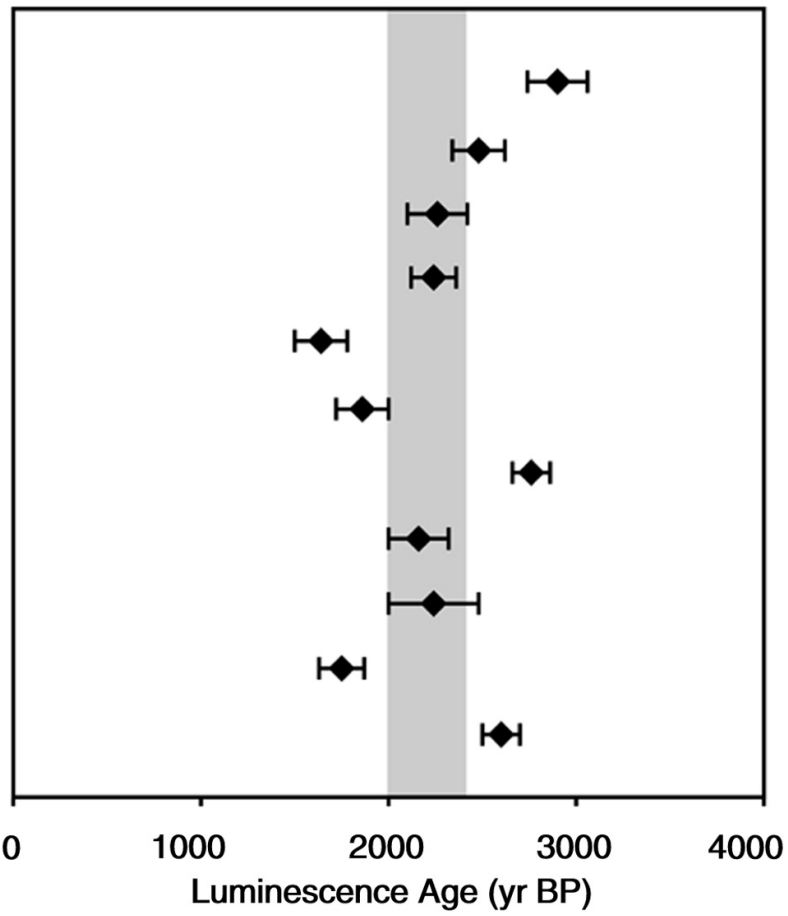

Fig. 3. Luminescence dates for Iron Age Scored Ware from southern Britain plotted against the expected age range (stippled zone) based on $14 \mathrm{C}$ age measurements for the same contexts (redrawn from Barnett 2000).

based on ${ }^{14} \mathrm{C}$ dates for the contexts that produced the pottery (Barnett 2000). However, the range of 1060 years for the luminescence ages (760 BC- AD $300)$ is substantially greater than the expected archaeological range of 400 years (400-1 BC), and four of the 11 luminescence two-sigma age ranges lie outside the expected age range (Fig. 3).

Johnson et al. (1980) report TL ages for measurements on Neolithic and Iron Age sherds from Europe, which typically overlap (at one sigma) both a series of calibrated radiometric radiocarbon ages on associated charcoal and AMS measurements on carbon included in the sherds (Fig. 4).

At Anzabegovo in Macedonia four sherds from an early Neolithic layer (Ib) were dated by the Research Laboratory for Archaeology and the History of Art at Oxford University. Only the mean ages are quoted (Gimbutas 1976). These range between 6390 and $6830 \mathrm{BC}$, which is $400-800$ years older than the calibrated ${ }^{14} \mathrm{C}$ ages of charcoal samples from the same layer (Fig. 5). It is not stated whether background measurements were made on soil samples associated with the sherds. If not, then the errors on the TL ages may be very large $( \pm 20 \%)$ and this may explain the apparent discrepancy between the TL and calibrated ${ }^{14} \mathrm{C}$ ages. 


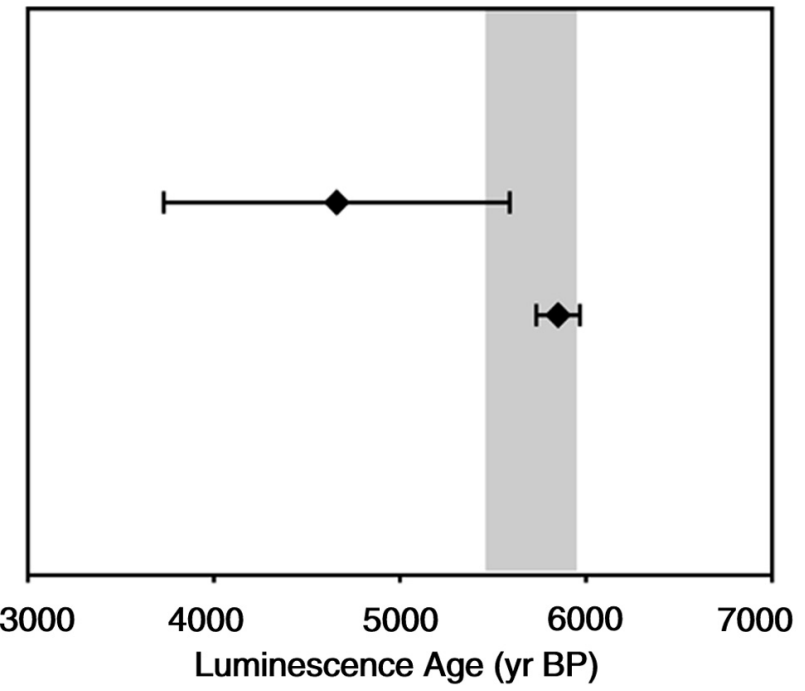

Fig. 4. Luminescence dates for Neolithic pottery from Egolzwil, Switzerland, plotted against the expected age range (stippled zone) based on ${ }^{14} \mathrm{C}$ age measurements for the same contexts (after Johnson et al. 1988).

Benkö et al. (1989) report 33 TL measurements on sherds from four sites in southeast Hungary and eastern Croatia - Gorsza, Tápé-Lebô, Tiszapolgár-Basatanya, and Vučedol - which span the period from Late Neolithic to Early Bronze Age (c. 5000-2000 cal $\mathrm{BC}$ ). The largest series (24 measurements) relates to graves in the Copper Age cemetery of TiszapolgárBasatanya. In each case the TL dates overlap (at onesigma) a series of calibrated ${ }^{14} \mathrm{C}$ ages on charcoal and/or bone, although the errors on the TL dates are large, ranging between \pm 8.7 and $\pm 15.5 \%$ (Fig. 6). However, the fit between the TL $/ 14 \mathrm{C}$ ages and the internal 'phasing' of the sites is less good.

It is also worth mentioning the study by Whittle and Arnaud (1975) of Neolithic and Chalcolithic pottery from megalithic monuments and settlement sites in the Alentejo region of central Portugal. Forty-two sherds from 9 sites were dated by the quartz inclusion technique (Fleming 1970). The dates for Neolithic contexts in relation to 'expected ages' are shown in Figure 7. In this case, the expected ages are derived from radiocarbon-based regional chronologies constructed in the 1960 s, rather than on ${ }^{14} \mathrm{C}$ dates from the sites under study, and may therefore require revision. The differences in the expected age ranges for the various sites are presumably based on typological considerations. Of the 35 measurements from Neolithic contexts, $20(c .57 \%)$ overlap the expected age ranges at one-sigma, while 6 dates, including the majority from Gateira, Gorginos and Carenque 2 , are significantly older than the expected ages. A further 7 sherds (from Giraldo, Serra de Baútas 'C' and Farisoa anta 1) produced ages that are significantly younger than the expected age range. Whittle and Arnaud (1975) argue that these sherds were attributed to the wrong archaeological context.

At the Scottish Universities Environmental Research Centre between 1986 and 1989 a number of dating projects were conducted in support of Scottish archaeological excavations. Field gamma spectrometry was always carried out during the excavations for the dual purpose of determining environmental dose rates from a range of contexts, and also ensuring a proper understanding of the nature of the dating problems being considered. Feldspar inclusion TL dating methods were used in this programme, resulting in approximately 200 luminescence dates from burnt stones and ceramics. Where external age controls were available the results appeared to be generally consistent. In two sites in particular Neolithic sequences were studied. At the site of Pool, on Sanday (Hunter \& MacSween 1991) more than 70 determinations were obtained from a sequence of vertically stratified midden deposits containing substantial quantities of Neolithic pottery. The majority of results were fully consistent with the original stratigraphic phasing of the site, although a small percentage appeared to indicate archaeological mixing processes or laboratory errors. The mean dates for successive phases produced approximately 100 year precision based on groups of 8-10 determina-

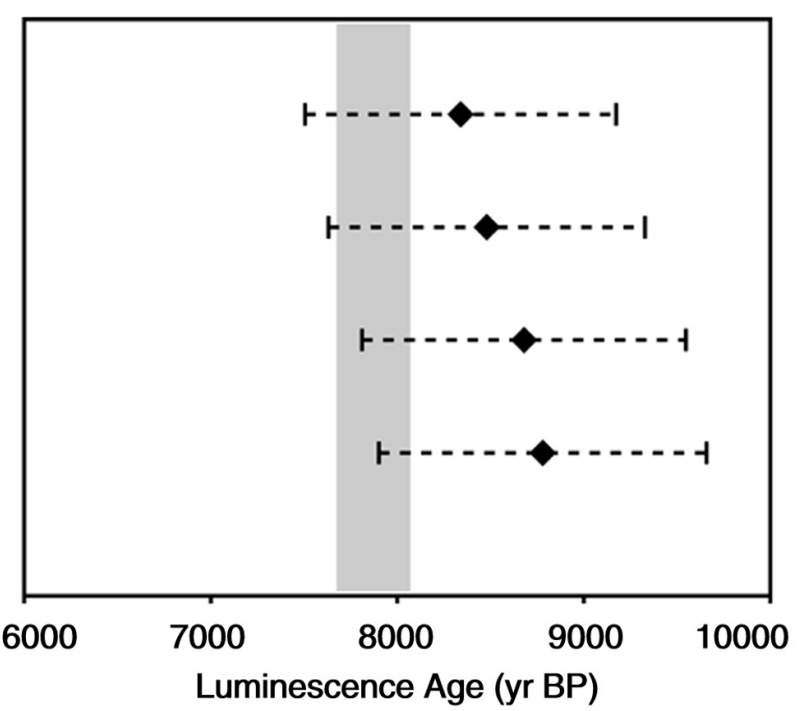

Fig. 5. Luminescence dates for Starčevo pottery from Anza 1b, Macedonia, plotted against the expected age range (stippled zone) based on ${ }^{14} \mathrm{C}$ age measurements on charcoal from the same layer (after Gimbutas 1976). The luminescence ages were obtained by the fine-grained TL technique (Zimmerman 1971). One-sigma errors of $\pm 20 \%$ have been assumed. 
tions per unit, with an overall chronology implying two major periods of activity at the site, in the late $5^{\text {th}} /$ early $4^{\text {th }}$ millennium $\mathrm{BC}$, and the late $3^{\text {rd }} /$ early $2^{\text {nd }}$ millennium $\mathrm{BC}$. The results are broadly consistent with both AMS and radiometric ${ }^{14} \mathrm{C}$ where available, but there are indications from the ${ }^{14} \mathrm{C}$ dates of mobility of small, carbonized plant fragments within the archaeological horizon. At the multi-phase site of Tofts Ness, also on Sanday (Dockrill et al. 1994), a series of ceramics and heated stones from the two earliest occupied structures were also dated, together with a series of hearthstones from a later prehistoric structure. On this site ${ }^{14} \mathrm{C}$ age measurements, based on carefully selected short-lived materials, were also available. The luminescence ages for the earliest two structures, based on the mean results from 4-5 samples per phase (Area A, $2600 \pm 240 \mathrm{BC}$; Area $\mathrm{B}, 2250 \pm 290 \mathrm{BC}$ ) are in the correct stratigraphic order and are consistent with the ${ }^{14} \mathrm{C}$ chronology within the precision of the calibration curve. These studies still await final archaeological publication,

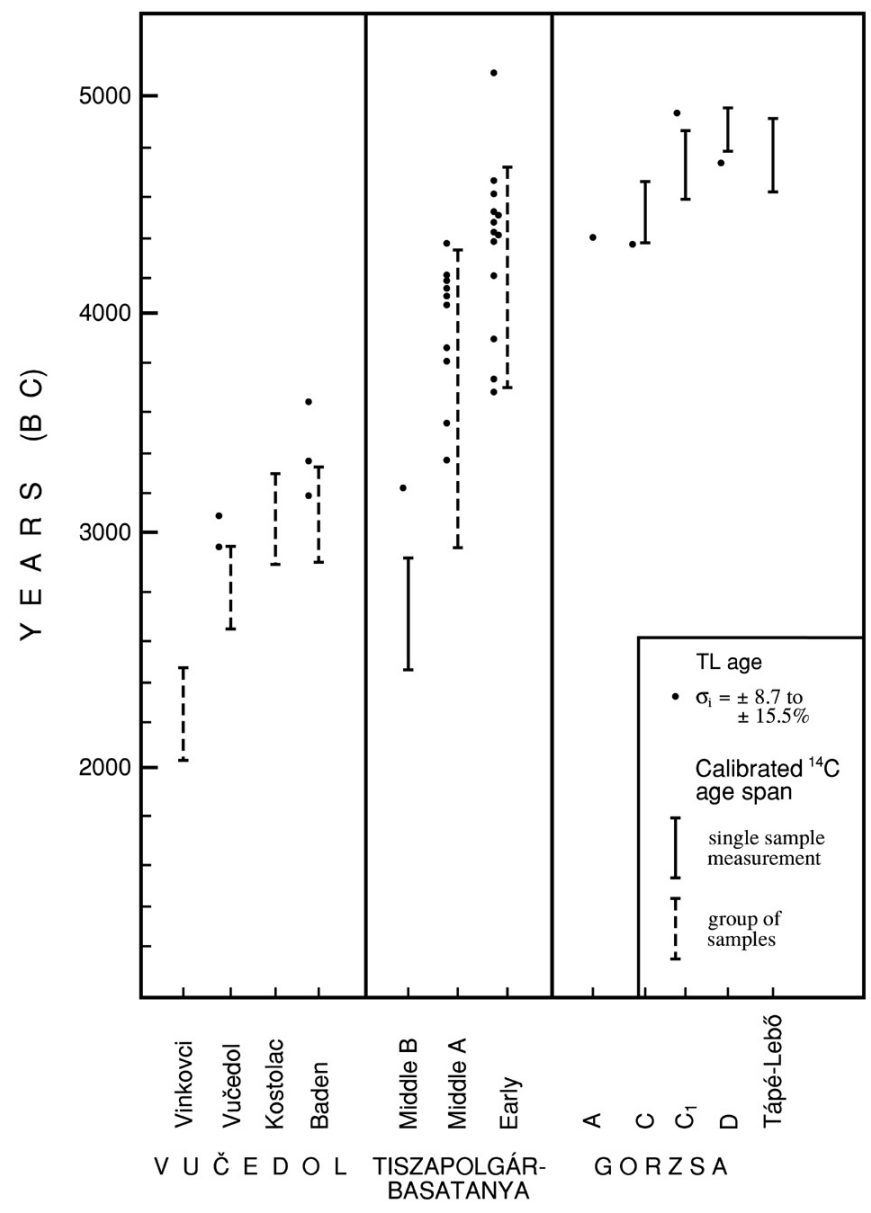

Fig. 6. Comparison of luminescence and calibrated ${ }^{14} \mathrm{C}$ dates for Late Neolithic to Early Bronze Age sites in southeast Hungary and eastern Croatia (after Benkö et al. 1989). The luminescence ages were obtained by the quartz inclusion TL technique (Fleming 1970). but are perhaps useful in indicating what can be achieved using multiple samples and close collaboration between dating laboratory and excavator.

Since this work was undertaken, there have been rapid advances in luminescence measurement methodology, which may have a constructive impact on the costs associated with such work, and the underlying reliability. However, some of the new procedures involve different luminescence signals, minerals and procedures, raising the need for careful validation to assess accuracy and reliability. Studies of this sort would benefit enormously from cross-validation relative to independent dating. In this respect the use of ${ }^{14} \mathrm{C}$ dating is critical, and the increasing potential of work on food residues from ceramics (see below) may offer important opportunities. Finally, it should be noted that the Neolithic, and its association with the introduction of ceramics, remains a vitally important period of prehistory, and therefore there are good reasons for undertaking work to enhance the absolute chronometric data sets which document this period, notwithstanding the practical challenges presented by material of this age.

\section{RADIOCARBON}

Direct ${ }^{14} \mathrm{C}$ dating of organic carbon derived from the matrix of archaeological ceramics was first attempted in the late 1950s and early 1960s (Ralph 1959; Evans \& Meggers 1962; Stuckenrath 1963; Taylor \& Berger 1968), however, the quantity of pottery required to provide sufficient carbon for radiometric ${ }^{14} \mathrm{C}$ analysis (of the order of 1 gram of elemental carbon) was often prohibitively large. With the advent of accelerator mass spectrometry (AMS) and the requirement for significantly less sample carbon (approximately 1 milligram), AMS ${ }^{14} \mathrm{C}$ analysis became a potentially very useful technique for direct dating of pottery $($ e.g. Hedges et al. 1992; Delqué Kolić 1995; Gomes \& Vega 1999). However, AMS ${ }^{14} \mathrm{C}$ dating of potsherds is still a complex issue because of the potential number of possible sources of carbon to be found in sherds. These include:

(1) Carbon that is derived from naturally occurring organic matter present in the clay matrix: De Atley (1980) has observed that primitive potters used a wide range of clays, including many poor grade varieties with high 
carbon contents. These could potentially vary in age from recently formed surface deposits to some of a significant geological age. Where these clays are from surface deposits, the organic material may derive from recently deposited vegetation, roughly contemporary with the time of manufacture of the ceramics. Conversely, older deposits, particularly those of a sedimentary nature, would contain organic matter of a significant age relative to the time of ceramic manufacturing. Inclusion of this latter material would consequently reflect an age for the ceramic sample that is earlier than the time of manufacture, if this carbon survived the firing process. Indeed, de Atley (1980) presents a number of examples of pottery, dated by ${ }^{14} \mathrm{C}$, which give radiocarbon ages that are significantly older than expected, while Johnson et al. (1988) present conclusive evidence that naturally occurring organic matter contained in clays can survive firing temperatures that are well in excess of those achieved by primitive techniques.

(2) Carbon that is derived from temper: The various forms of temper include grasses, straw, chaff, dung, calcite and ground shells (Evin et al. 1989; Roosevelt et al. 1991; Hedges et al. 1992; Kuzmin \& Keally 2001). Those forms that are organic and terrestrial in nature would typically be contemporary with the manufacturing of the pottery and would represent the carbon component that would be most suitable for direct dating of the pottery. However, the use of shell material presents two problems:

a. The initial ${ }^{14} \mathrm{C}$ activity: For marine shells, there is a marine reservoir age to be taken into account (e.g. Harkness 1981). For freshwater snails, there is the potential for a hard water effect while for terrestrial species, the digestion of significant amounts of carbonate carbon has to be considered (Evin et al. 1980) and

$\boldsymbol{b}$. There is the potential for the carbonate temper (mainly calcium carbonate) to be converted to calcium oxide. During cooling and subsequent time, the calcium oxide may combine with carbon dioxide to reform calcium carbonate. De Atley (1980) notes that tempers composed of shell may therefore contain carbon from three sources, namely, from the original shell, the ambient atmosphere during firing of the clay, and the depositional environment subsequent to firing.

(3) From fuel in the kiln: Reduced oxygen conditions in the kiln will result in incomplete combustion of the fuel, giving rise to soot and smoke production, both of which can become absorbed by the pot whilst being fired. Provided that the timber used as fuel is recently felled (with respect to the firing of the pot) and does not suffer from the 'old wood' effect, i.e. it is from comparatively short-lived species, then the carbon incorporated from this source will be suitable for dating the age of the potsherd. A similar effect to that of 'old wood' would apply where peat was used as fuel. Delqué Kolić (1995) demonstrated that low temperature combustion of surface material from experimentally prepared potsherds showed some promise in giving a $\mathrm{CO}_{2}$ sample for AMS measurement that was predominantly derived from fuel smoke, however, the presence of carbon derived from the clay itself could not be discounted. Furthermore, when this type of sampling was used for archaeological sherds, the results were less conclusive because of external contaminants from the depositional environment.

(4) From use of the pottery: In this context, the carbon would be derived from adhering food residues

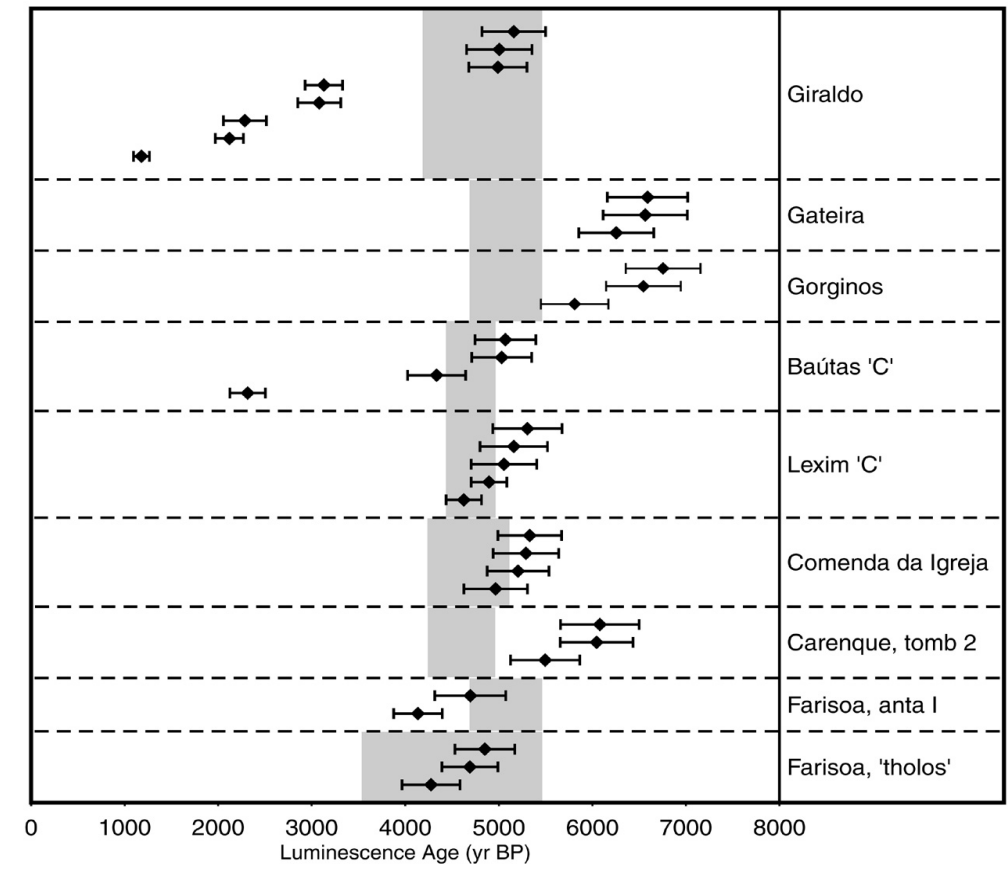

Fig. 7. Luminescence dates for Neolithic pottery from megalithic monuments (Carenque, Comenda da Igreja Farisoa, Gateira and Gorginos) and settlement sites (Baútas, Giraldo and Lexim) in central Portugal (after Whittle \& Arnaud 1975). The luminescence ages were obtained by the quartz inclusion TL technique (Fleming 1970). 
and/or soot and smoke absorbed during cooking. Again, there is the possibility that the soot/smoke may derive from old wood (or peat) being used as the fuel and this could result in a ${ }^{14} \mathrm{C}$ age that is hundreds of years older than the time of use of the pot. Food residues can also be problematic. They are firstly not all that common and are also highly susceptible to geochemical contamination, although this can probably be removed by chemical pre-treatment. In addition, there is also the question of what type of food source gave rise to the residue. If the residue was derived from a terrestrial plant/animal product then, in the absence of contamination, this material would yield a suitable age for the time of use, however, if the residue was derived from fish/shellfish (marine or fresh water), ${ }^{14} \mathrm{C}$ analysis is likely to give a radiocarbon age that is hundreds of years older than the date of the sherd. Work by Heron et al. (1991) has demonstrated that the migration of soil lipids into long-buried potsherds was negligible and did not affect the residue composition of the vessel. In addition, they also observed that the effects of microbial reworking of the organic residues absorbed in sherds were negligible and that preservation of lipids in the porous microstructure of the vessel was excellent. The nature and variation of the extracts from sherds was indicative of residues consistent with vessel usage rather than being derived from other sources. The authors conclude that sherds found to have a high yield of well-preserved organic constituents absorbed during usage could potentially be used for ${ }^{14} \mathrm{C}$ dating.

\section{Secondary contamination from carbon contai-} ning components in the surrounding soil: Once in its depositional environment, the potsherd is subject to the same potential contaminants from the surrounding soil as any other sample that may be radiocarbon dated. These would include humic substances, lipids, rootlets, etc. Gabasio et al. (1986) suggest that all of these organic elements, the mean age of which is a function of the rate of turnover of organic carbon in the context under consideration, are younger than the potsherd. However, this would only be true if the depositional environment were the surface soil. Instances where the potsherds are part of an infill could mean that their placement is in a context where the surrounding organic matter is, on average, older than the date of manufacture of the pot. Gabasio et al. (1986) propose that treatment of the potsherd with sodium hydroxide or pyrophosphate would probably eliminate most of the secondary carbon although they do not present direct evidence of this occurring in potsherds.
Of the five potential sources discussed above, those most likely to produce reliable ${ }^{14} \mathrm{C}$ ages would be: (1) Temper derived from terrestrial plant material (straw, chaff, dung, etc), and (2) Food residues that are identifiably of a terrestrial origin.

Stäuble (1995) has demonstrated that in sherds from the earliest LBK contexts in central Europe, the organic temper-derived ages were significantly older than expected. This was thought to be due to the combustion of a proportion of the organic matter originally associated with the clay. In contrast, organic food residues gave rise to ${ }^{14} \mathrm{C}$ ages that were both consistent and expected.

Hedges et al. (1992) undertook direct dating of pottery from a number of sites in Serbia, China, Thailand, Brazil and the USA. In the case of the Starčevo pottery from Serbia (expected age of $c .7000 \mathrm{BP}$ ), they observed that the temper, which consisted of chaff or dung, had not been completely burned out because of low firing temperature. Radiocarbon dating of a humic acid fraction and a residual fraction (which appears to be a combination of temper and carbon from the clay) generally produced what the authors considered to be unreliable ages. Typically, the residue samples were older than they expected because of incorporation of geological carbon from the clay, and the humic samples were younger than expected. Where humic acid and residue ages were in agreement, the combined age was consistent with the archaeologically expected age (Fig. 8).

With respect to the Asian material, the separated temper fraction, which could be expected to be the most reliable, generally fell between the humic acid and residue ages. Lipid-derived ages were generally considered to be unreliable, although identification of the components of this fraction was not undertaken. Nevertheless, Heron et al. (1991) maintain that migration of soil lipids into long-buried potsherds was negligible and did not affect the residue composition of the vessel, implying that the analyses undertaken by Hedges et al. (1992) should produce reliable ages without resorting to identifying the lipid components. Hedges et al. (1992) concluded from their studies that organic rich coatings such as food or soot gave fairly reliable ages and further that the validity of the age was strengthened if a second fraction (e.g. humic substances) gave a similar age. Temper samples that could be physically removed from sherds were also generally reliable but the authors again concluded that validity was strengthened by similar ages from other frac- 


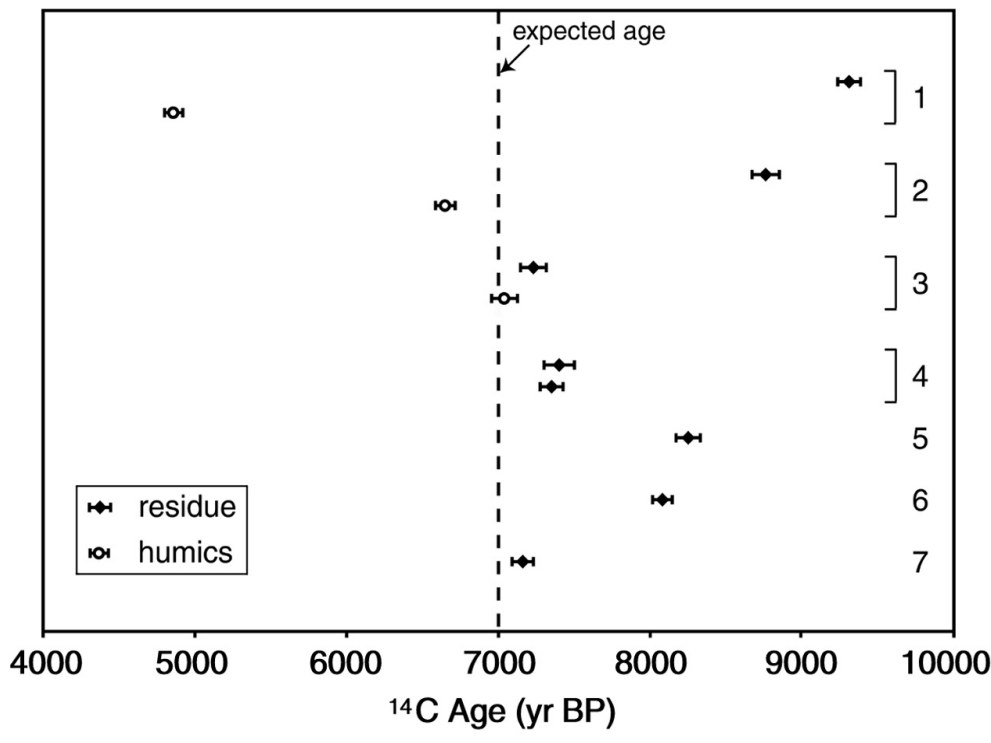

Fig. 8. ${ }^{14} \mathrm{C}$ dates for Starčevo pottery from Serbia: $1=$ Banja; $2=$ Grivac; 3 = Vinča; 4 = Divostin; 5 = Dobrovodica; $6=$ Star čevo-Grad; 7 = Rudnik (based on data from Gowlett et al. 1987; Manson 1990; Hedges et al. 1992).

tions. Most recently, Stott et al. (2001) have produced valid age measurements, made on carbon from single fatty acid compounds isolated from cooking vessel residues.

\section{ARCHAEOMAGNETIC INTENSITY}

A promising, but as yet not widely applied, method for dating pottery is archaeomagnetic intensity analysis. The basic principle of this method is as follows. Clay often contains magnetic minerals (e.g. magnetite and hematite) as impurities and when heated to a point above the 'blocking temperature' of those minerals $\left(500-700^{\circ} \mathrm{C}\right)$, the magnetic particles may record the direction and strength of the earth's magnetic field at that time. This type of magnetization is called thermoremanent magnetism (TRM). Since the earth's magnetic field changes in both direction and strength over time and space, it is possible to determine when an object of baked clay was last subjected to temperatures that were high enough to permit acquisition of TRM, by comparing its magnetic parameters with the known geomagnetic record for a particular region. Dating is only possible when a reference curve is established for the region concerned. The reference curve has to be calibrated by some chronometric dating method(s), ideally a high precision technique, e.g. historical records or dendrochronology. ${ }^{14} \mathrm{C}$ and TL can be used, but any uncertainty associated with such dates will also limit their ability to be used to calibrate the archaeomagnetic data.
Currently, within Europe one of the most detailed records available is for southeast Europe, which is based on material from radiocarbon-dated sites in Bulgaria and Serbia. With a few gaps, this reference curve covers the last 8000 yrs (Kovacheva 1997). The Bulgarian curve records changes in the direction of the geomagnetic field (inclination and declination) and variations in intensity. Directional data are not particularly useful when dealing with moveable objects, e.g. pots, but intensity values can be obtained from sherds and compared against the master curve.

In an effort to refine the chronology of the Starčevo culture, Manson (1990; Manson \& Schmidt 1991) undertook archaeomagnetic intensity analyses of potsherds from nine Starčevo culture sites in Serbia. The standard double-heating method of Thellier and Thellier (1959) was used. This method is tedious and time-consuming, but it has features built into it that allow researchers to assess the reliability of the results for each sample. Any sample that fails to meet the standards for internal consistency can be removed from further consideration. If rigorous standards are followed, it is not unusual for the failure rate to be rather high - often, nearly a third of the samples will be rejected from a study. However, the remaining samples can then be used with a fairly high degree of confidence.

An average intensity value was obtained for each Starčevo culture site, and then compared against the published archaeointensity curve and tables for southeast Europe, particularly that published by Kovacheva and Veljovich (1985). Since the magnetic field intensity does not vary uniquely through time, a measured intensity may correspond to more than one possible age. Other evidence must be used to determine the most likely position of a site's intensity value on the archaeointensity curve. In the absence of reliable radiocarbon dates and deeply stratified sites, Manson's study utilized the ceramic typology of Aranđelović-Garašanin (1954) to determine the relative sequence of the sites and the most likely position of each site on the curve. In this way, Manson felt that most of the sites could be dated to within a 100-year time period (Fig. 9).

Manson's dating of Starčevo sites rests on two principal assumptions: (1) Each site represents a single 
phase of occupation with a short lifespan. (2) Aranđelović-Garašanin's ceramic typology is valid. The first assumption was based on the size, depth, and overall composition of the sites in the study (see Manson 1995). The second assumption appears to be supported at the few Starčevo sites that have well-defined vertical stratigraphy, such as Rudnik (Garašanin 1979). However, neither assumption has been rigorously tested by radiometric dating. Nevertheless, if suitable archaeointensity curves have been established for a region, archaeomagnetic intensity analysis shows great potential as a dating technique.

\section{CONCLUSIONS}

Pottery sherds can be dated by at least four direct methods, three of which involve physical analysis of the sherd. Each method has its own sources of error and uncertainty and all, on occasion, produce anomalous results. Therefore, as Johnson et al. (1986) have observed, a combination of at least two of the methods is essential for reliable dating. One factor that is apparent from the literature on this subject is that most applications of luminescence and ${ }^{14} \mathrm{C}$ to pottery dating have been performed exclusively by dating 'specialists' with little input from archaeologists, and in some cases it is clear that there has been inadequate 'control' over the selection of samples for dating. Also, while many laboratories have attempted to date pottery, most studies have been on an ad hoc basis, and comparatively few of them have fully tested the reliability of the measurements. Yet, it is evident from the foregoing discussion that an effective collaboration between archaeologist and laboratory is critical to the successful application of luminescence dating, not least so that sample contexts can be dealt with in an appropriate way. This is also true of direct ${ }^{14} \mathrm{C}$ dating of pottery where a full understanding of the material origins needs to be coupled with an appreciation of the ceramic tradition and associated artefacts.

There is enormous scope for further studies involving the physical techniques and, in this respect, archaeomagnetic intensity analysis holds great appeal, especially in relation to the Neolithic of southeast Europe. However, in the absence of $14 \mathrm{C}$ or luminescence dates on the same sherds, access to 'closed' pottery assemblages and suitable precision ${ }^{14} \mathrm{C}$ age measurements on associated archaeological materials from the same context are required. Ultimately, this necessitates that field techniques pay

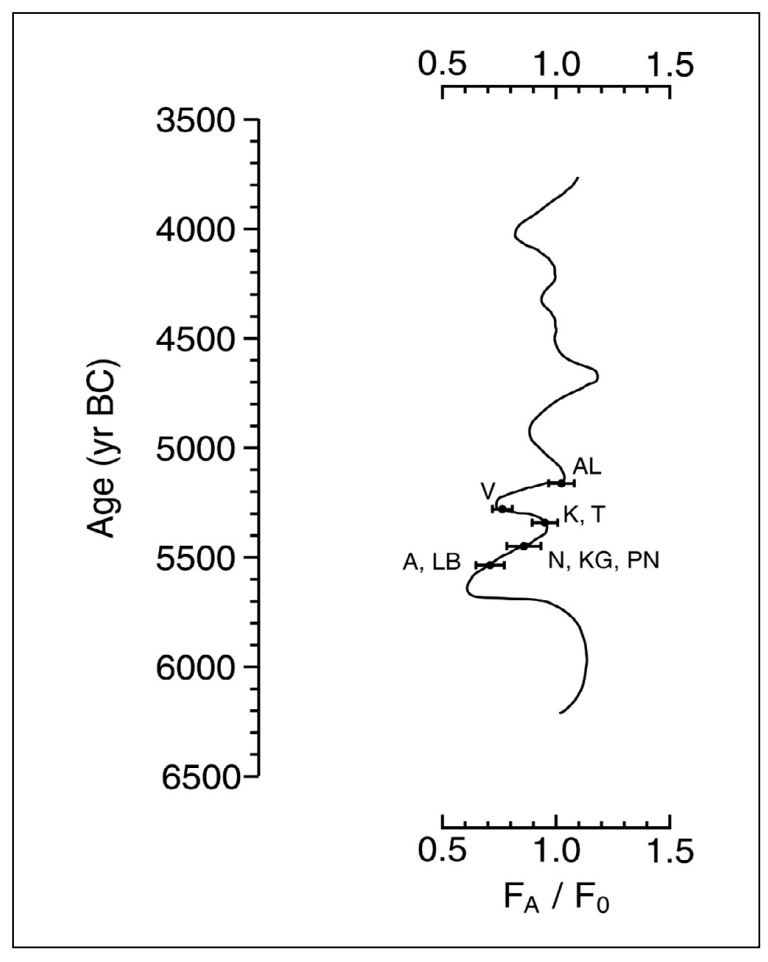

Fig. 9. Starčevo sites on the archaeomagnetic intensity curve: $A=A t ; A L=$ Aradac-Leje; $K=K o z l u k ; K G$ = Kaonik-Gradina; LB = Ludaš-Budžak; $N$ = Nosa; $P N=$ Pančevo-Nadela; $T=$ Tečić; $V=$ Vrtište (after Manson \& Schmidt 1991; based on Kovacheva \& Veljovich 1985).

greater attention to site stratigraphy and to understanding site formation processes.

There are significant potential benefits in combining work on all methods. Good luminescence, radiocarbon and archaeomagnetic intensity cross-validation would be mutually beneficial, as well as providing the absolute chronometric framework required for assessing the validity of ceramic typologies. 


\section{REFERENCES}

AITKEN M. J. 1990. Science-based Dating in Archaeology. London: Longman.

AITKEN M. J., ZIMMERMAN D. W. and FLEMING S. J. 1968. Thermoluminescent dating of ancient pottery. Nature 219: 442-445.

ARANĐELOVIĆ-GARAŠANIN D. 1954. Starčevačka kultura. Ljubljana.

BARNETT S. M. 2000. Luminescence dating of pottery from later prehistoric Britain. Archaeometry 42 (2): 431-457.

BENKÖ L., HORVÁTH F., HORVATINČIĆ N. and OBELIĆ B. 1989. Radiocarbon and thermoluminescence dating of prehistoric sites in Hungary and Yugoslavia. Radiocarbon 31: 992-1002.

BRUKNER B. 1979. Körös-grupa. In Praistorija Jugoslavenskih Zemalja II: 213-226. Sarajevo: Akademija Nauka i Umjetnosti Bosne i Hercegovine. Centar za balkanološka ispitivanja.

DE ATLEY S. P. 1980. Radiocarbon dating of ceramic materials: progress and prospects. Radiocarbon 22 (3): 987-993.

DELQUÉ KOLIĆ E. 1995. Direct radiocarbon dating of pottery: selective heat treatment to retrieve smokederived carbon. In G. T. Cook, D. D. Harkness, B. F. Miller and E. M. Scott (eds), Proceedings of the 15th International $14 \mathrm{C}$ Conference. Radiocarbon 37(2): 275-284.

DIMITRIJEVIĆ S. 1974. Problem stupnjevanja Starčevačke kulture s posebnim obzirom na doprinos južnopanonskih nalazišta rješavanju ovog problema. In N. Tasić (ed.), Počeci ranih zemljoradničkih kultura u Vojvodini i Srpskom Podunavlju. Materijali 10: 59-93.

1979. Sjeverna zona. In Praistorija Jugoslavenskih Zemalja II: 229-360. Sarajevo: Akademija Nauka I Umjetnosti Bosne I Hercegovine. Centar za balkanološka ispitivanja.

DOCKRILL S. J., BOND J. M., MILLES A., SIMPSON I. and AMBERS J. 1994. Tofts Ness, Sanday, Orkney. An integrated study of a buried Orcadian landscape. In R. Luff and P. Rowley-Conwy (eds.), Whither Environmental Archaeology: 115-132.
EHRICH R. W. 1977. Starčevo revisited. In V. Markotic (ed.), Ancient Europe and the Mediterranean: 59-67.

EVANS C. and MEGGERS B. 1962. Use of organic temper for C-14 dating in lowland South America. American Antiquity 28: 243-245.

EVIN J., GABASIO M. and LEFÈVRE J-C. 1989. Preparation techniques for radiocarbon dating of potsherds. Radiocarbon 31(3): 276-283.

FEWKES V. J. 1935. On the interpretation and dating of the site of 'Belo Brdo' at Vinča in Yugoslavia. Proceedings of the American Philosophical Society 78: 651-672.

FLEMING S. J. 1970. Thermoluminescent dating: refinement of the quartz inclusion method. Archaeometry 12: 133-145.

GABASIO M., EVIN J., ARNAL G. B. and ANDRIEUX P. 1986. Origins of carbon in potsherds. Radiocarbon 28(2A): 711-718.

GARAŠANIN M. 1979. Centralnobalkanska zona. In Praistorija Jugoslavenskih Zemalja II: 79-212. Sarajevo: Akademija Nauka I Umjetnosti Bosne I Hercegovine.

GIMBUTAS M. 1974 . Anza, ca. $6500-5000$ B.C.: A cultural yardstick for the study of Neolithic southeast Europe. Journal of Field Archaeology 1: 26-66.

1976. Chronology. In M. Gimbutas (ed.), Neolithic Macedonia as Reflected by Excavation at Anza, Southeast Yugoslavia: 29-77.

GOMES D. C. and VEGA 0. 1999. Dating organic temper of ceramics by AMS: sample preparation and carbon evaluation. Radiocarbon 41(3): 315-320.

GOWLETT J. A. J., HEDGES R. E. M., LAW I. A. and PERRY C. 1987. Radiocarbon dates from the Oxford AMS system: Archaeometry Datelist 5. Archaeometry 29(1): 125-155.

HARKNESS D. D. 1983. The extent of natural ${ }^{14} \mathrm{C}$ deficiency in the coastal environment of the United Kingdom. In W. G. Mook and H. T. Waterbolk (eds.), PACT 8: First International Symposium on ${ }^{14} \mathrm{C}$ and Archaeology, Groningen 1981: 351-364. 
HEDGES R. E. M., TIEMEI C. and HOUSLEY R. A. 1992. Results and methods in the radiocarbon dating of pottery. Radiocarbon 34(3): 906-915.

HERON C., EVERSHED R. P. and GOAD L. J. 1991. Effects of migration of soil lipids on organic residues associated with buried potsherds. Journal of Archaeological Science 18: 641-659.

HUNTER J. R. and MACSWEEN A. 1991. A sequence for the Orcadian Neolithic? Antiquity 65: 911-914.

JOHNSON J. S., CLARK J., MILLER-ANTONIO S., ROBINS D., SCHIFFER M. B. and SKIBO J. M. 1988. Effects of firing temperature on the fate of naturally occurring organic matter in clays. Journal of Archaeological Science 15: 403-414.

JOHNSON R. A., STIPP J. J. and TAMERS M. A. 1986. Archeologic sherd dating: comparison of thermoluminescence dates with radiocarbon dates by beta counting and accelerator techniques. Radiocarbon 28 (2A): $719-725$.

KOROŠEC B. 1973. Application de méthodes d'analyse statistique au problème de la chronologie du site de Starčevo. Arheološki Vestnik - Acta Archaeologica 24: 271-302.

KOVACHEVA M. and VELJOVICH D. 1985. Arheomagnitno izsledvane na praistoricheski obekti ot NRB i SFRYU. Arheologia 4(2): 21-26.

KOVACHEVA M. 1997. Archaeomagnetic database from Bulgaria. Physics of the Earth and Planetary Interiors 102: 145-151.

KUZMIN Y. V and KEALLY C. T. 2001. Radiocarbon chronology of the earliest Neolithic sites in East Asia. Proceedings of the $17^{\text {th }}$ International Radiocarbon Conference. Radiocarbon 43(2B): 1121-1128.

MANSON J. L. 1990. A Reanalysis of Starčevo Culture Ceramics: Implications for Neolithic Development in the Balkans. Ph.D. dissertation, Southern Illinois University, Carbondale.

1995. Starčevo pottery and Neolithic development in the central Balkans. In W. K. Barnett and J. W. Hoopes (eds.), The Emergence of Pottery: Technology and Innovation in Ancient Societies: 65-77.

MANSON J. L. and SCHMIDT V. A. 1991. Archaeomagnetic dating of Neolithic Yugoslavian potsherds. Pa- per presented at The 56 th Annual Meeting of the Society for American Archaeology, New Orleans.

MICHELS J. W. 1973. Dating Methods in Archaeo$\log y$. New York: Seminar Press.

MILOJČIĆ V. 1950. Körös-Starčevo-Vinča. Mainz: Reinecke Festschrift.

PETRIE F. 1904. Methods and Aims in Archaeo$\log y$. London: Macmillan.

PLOG S. 1980. Stylistic Variation in Prehistoric Ceramics. Cambridge: Cambridge University Press.

PRESCOTT J. R. and ROBERTSON G. B. 1997. Sediment dating by luminescence: a review. Radiation Measurements 27(5/6): 893-922.

RALPH E. K. 1959. University of Pennsylvania radiocarbon dates III. American Journal of Science Radiocarbon Supplement 1: 45-58.

RICE P. M. 1987. Pottery Analysis. A Sourcebook. Chicago: University of Chicago Press.

ROBERTS R. G. 1997. Luminescence dating in archaeology: from origins to optical. Radiation Measurements 27(5/6): 819-892.

ROOSEVELT A. C., HOUSLEY R. A., IMAZIO DA SILVA M., MARANCA S. and JOHNSON R. 1991. Eighth millennium pottery from a prehistoric shell midden in the Brazilian Amazon. Science 254: 1621-1624.

SINOPOLI C. M. 1991. Approaches to Archaeological Ceramics. New York: Plenum.

SREJOVIĆ D. 1972. Europe's First Monumental Sculpture: New Discoveries at Lepenski Vir. London: Thames and Hudson.

STOTT A. W., BERSTAN R., EVERSHED P., HEDGES R. E. M., BRONK RAMSEY C. and HUMM M. J. 2001. Radiocarbon dating of single compounds isolated from pottery cooking vessel residues. Proceedings of the $17^{\text {th }}$ International Radiocarbon Conference. Radiocarbon 43(2A): 191-197.

STÄUBLE H. 1995. Radiocarbon dates of the earliest Neolithic in Central Europe. In G. T. Cook, D. D. Harkness, B. F. Miller and E. M. Scott (eds.), Proceedings of the $15^{\text {th }}$ International ${ }^{14} \mathrm{C}$ Conference. Radiocarbon 37(2): 227-237. 
STUCKENRATH R. 1963. University of Pennsylvania radiocarbon dates VI. Radiocarbon 5: 82-103.

TAYLOR R. E. and BERGER R. 1968. Radiocarbon dating of the organic portion of ceramic and wattleand-daub house construction material of low carbon content. American Antiquity 33: 363-366.

THELLIER E. and THELLIER 0. 1959. The intensity of the earth's magnetic field in the historical and geological past. Izvestiya. Geophysics Series 7: 929-949.
WHALLON R. and BROWN J. A. (eds.) 1981. Essays in Archaeological Typology.

WHITTLE E. H. and ARNAUD J. M. 1975. Thermoluminescent dating of Neolithic and Chalcolithic pottery from sites in central Portugal. Archaeometry 17: 5-24.

ZIMMERMAN D. W. 1971. Thermoluminescent dating using fine grains from pottery. Archaeometry 13(1): $29-52$. 